\title{
The giant Kamoa-Kakula project in the Democratic Republic of Congo
}

\author{
by S. Amos*, V. Nkuna ${ }^{\dagger}$, and B. Matsetela ${ }^{\dagger}$
}

\section{Synopsis}

The Kamoa-Kakula copper project-a joint venture between Ivanhoe Mines, Zijin Mining Group Co. Ltd, and the government of the Democratic Republic of Congo-has been independently ranked as the world's largest undeveloped high-grade copper discovery by international mining consultant Wood Mackenzie. It is a very large, near-surface stratiform copper deposit with adjacent prospective exploration areas within the Central African Copperbelt, approximately $25 \mathrm{~km}$ west of the town of Kolwezi and about $270 \mathrm{~km}$ west of the provincial capital of Lubumbashi. A phased development approach is currently envisaged. The first phase of the project involves the development of a $6 \mathrm{Mt} / \mathrm{a}$ underground mine and surface processing complex (dual stream concentrator) at the Kakula deposit, a discovery announced in early 2016. The second phase involves an integrated $12 \mathrm{Mt} / \mathrm{a}$ two-stage development, beginning with initial production from the Kakula mine, to be followed by a subsequent, separate underground mining operation at the nearby Kansoko mine, along with the construction of a smelter.

Keywords

copper, Democratic Republic of Congo, mineral resources, economic evaluation, staged development.

\section{Project description and location}

The Kamoa-Kakula project comprises a newly discovered, very large stratiform copper deposit with adjacent prospective exploration areas, located within the Central African Copperbelt in Lualaba Province, Democratic Republic of Congo (DRC). The Kamoa-Kakula project lies approximately $25 \mathrm{~km}$ west of the town of Kolwezi and about $270 \mathrm{~km}$ west of Lubumbashi. Ivanhoe owns a $49.5 \%$ share interest in Kamoa Holding, an Ivanhoe subsidiary that currently owns $80 \%$ of the project. Zijin Mining owns a $49.5 \%$ share interest in Kamoa Holding, which it acquired from Ivanhoe in December 2015 for an aggregate cash consideration of US $\$ 412$ million. The remaining $1 \%$ interest in Kamoa Holding is held by privately-owned Crystal River.

The Kamoa-Kakula project consists of the Kamoa exploitation licences (exploitation permits 12873,13025 , and 13026, which cover an area of $\left.397.4 \mathrm{~km}^{2}\right)$ and one exploration licence (exploration permit 703 covering an area of $12.74 \mathrm{~km}^{2}$ ). The Kamoa exploitation licences, approved 20 August 2012, grant Kamoa Copper the right to explore for, develop, and exploit copper and other minerals, for an initial 30-year term, expiring on 19 August 2042. The permits can then be extended for 15-year periods until the end of the mine's life.

The Kamoa-Kakula project area is sparsely inhabited. The company is preparing a resettlement plan that will identify any traditional owners within the project area, but no major resettlement is expected.

Compensation related to land access for the exploration programmes completed to date has been successfully negotiated and has not amounted to a material cost to the company.

Pursuant to the DRC Mining Code, the grant of the Kamoa exploitation licences triggered an obligation on the part of Ivanhoe to transfer to a DRC state-owned nominee, for no consideration, a non-dilutable $5 \%$ interest in Kamoa Copper within 30 working days. On 11 September 2012, the company satisfied this obligation by transferring $5 \%$ of the share capital of Kamoa Copper to the DRC state. In addition, during the application process for the grant of the Kamoa exploitation licences, Ivanhoe engaged in discussions with the DRC government regarding the nature of the DRC's participation in the project. These discussions culminated in Ivanhoe offering to transfer a further 15\% interest in Kamoa Copper to the DRC on terms to be negotiated between Ivanhoe and the DRC government. On 11 November 2016, an additional 15\% interest in Kamoa Copper was transferred to the DRC by Kamoa Holding. Ivanhoe and Zijin Mining have also indicated their willingness to participate, in conjunction with the DRC government, DRC state-owned utilities, other mining companies, and interested parties in

\footnotetext{
* Kamoa Copper SA, South Africa.

+ Ivanhoe Mines, South Africa.

(c) The Southern African Institute of Mining and Metallurgy, 2018. ISSN 2225-6253. This paper was first presented at the Copper Cobalt Africa, incorporating the 9th Southern African Base Metals Conference, 9-12 July 2018, Avani Victoria Falls Resort, Livingstone, Zambia.
} 


\section{The giant Kamoa-Kakula project in the Democratic Republic of Congo}

the region in the enhancement of rail and power infrastructure in Lualaba and adjacent provinces.

\section{History}

The Kamoa-Kakula project represents the first discovery of a major copper deposit or district in Lualaba Province since the early 1900s, and indicates the prospectivity of the Katangan section of the Central African Copperbelt for discovery of additional copper deposits. During the period 1971-1975, the Tenke Fungurume Consortium, operating as the Societé Internationale Des Mines du Zaïre, undertook grassroots exploration over an area that extended southwest from Kolwezi towards the Zambian border. A helicopter-supported regional stream sediment sampling programme was completed in 1971. No sample location information is available for any sampling that may have been done within the Kamoa-Kakula project area during this period.

In 2003, Ivanhoe acquired a significant groundholding, including the permit areas that now comprise the KamoaKakula project. Work completed to date includes data compilation; acquisition of satellite imagery; geological mapping; stream sediment and soil geochemical sampling; an airborne geophysical survey that comprised total field magnetic intensity, horizontal and longitudinal magnetic gradient, multi-channel radiometric, linear and barometric, and altimetric and positional data; acquisition of whole-rock major and trace element data from selected intervals of the mineralized zone and footwall sandstone in dril-lhole DKMC_DD019; and aircore, reverse circulation (RC), and core (DDC) drilling.

An initial Mineral Resource Estimate was prepared by AMEC for the project in 2009. The estimate was updated in 2010, 2011, 2012, 2014, 2016, 2017, and 2018.

\section{Geology and mineralization}

The metallogenic province of the Central African Copperbelt is hosted in metasedimentary rocks of the Neoproterozoic Katanga Basin. The lowermost sequences were deposited in a series of restricted rift basins that were then overlain by laterally extensive, organic-rich marine siltstones and shales. These units contain the bulk of the ore deposits within the Central African Copperbelt (Kamoa-Kakula is, however, an exception to this). This is in turn overlain by an extensive sequence of mixed carbonate and clastic rocks of the Upper Roan Group. The Roan Group now forms a northerlydirected, thin-skinned thrust-and-fold orogenic system, the Lufilian Arc, which resulted from the convergence of the Congo and Kalahari cratons. The metallogenic province is divided into two distinct districts: the Zambian and Congolese or Katangan copperbelts.

The Katangan Basin overlies a composite basement made up of older, multiply deformed and metamorphosed intrusions that are mostly of granitic affinity and supracrustal metavolcanic-sedimentary sequences. In Zambia, this basement is mainly Paleoproterozoic in age (2100-1900 Ma), whereas in the Kamoa-Kakula region, only Mesoproterozoic basement (ca. 1100-1300 Ma) is known.

The majority of the Kamoa-Kakula project area lies on a broad, gentle plateau between two major north-northeasttrending structures. To the east, and identified primarily by airborne magnetics, is the Kansoko Trend, which is the interpreted boundary with the External Fold and Thrust Belt. The geology of the Kansoko Trend is currently poorly defined. To the west is a prominent escarpment and magnetic feature named the West Scarp Fault.

The Kamoa-Kakula project is located in a broadly folded terrane centred on the Kamoa and Makalu domes between the West Scarp Fault and Kansoko Trend. The domes form erosional windows exposing the redox boundary between the underlying haematitic (oxidized) Roan sandstones and the overlying carbonaceous and sulphidic (reduced) Grand Conglomerate diamictite (host to the mineralization). Unlike the tectonically dismembered deposits of the Katangan Copperbelt and the External Fold and Thrust Belt, the host rocks at Kamoa-Kakula are intact and relatively undisturbed.

Mineralization at the Kamoa-Kakula Project has been defined over an irregularly shaped area of $27 \mathrm{~km} \times 15 \mathrm{~km}$. Mineralization is typically stratiform and vertically zoned from the base upwards with chalcocite $\left(\mathrm{Cu}_{2} \mathrm{~S}\right)$, bornite $\left(\mathrm{Cu}_{5} \mathrm{FeS}_{4}\right)$, and chalcopyrite $\left(\mathrm{CuFeS}_{2}\right)$. There is significant pyrite mineralization above the mineralized horizon that could possibly be exploited to produce pyrite concentrates for sulphuric acid production (needed at oxide copper mines in the DRC).

The dip of the mineralized body ranges from $0^{\circ}$ to $10^{\circ}$ near-surface above the Kamoa dome to $15^{\circ}$ to $20^{\circ}$ on the flanks of the dome. Mineralization thicknesses at a $1.0 \% \mathrm{Cu}$ cut-off grade range from $2.3 \mathrm{~m}$ to $15.8 \mathrm{~m}$ (for Indicated Mineral Resources). The deposit has been tested locally from below surface to depths of more than $1560 \mathrm{~m}$, and remains open to the east and south.

Mineralization in the majority of the Katangan Copperbelt orebodies, such as at those located at Kolwezi and TenkeFungurume, is oxide in nature and is hosted in the Mines Subgroup (R2). The mineralization at Kamoa-Kakula differs from these deposits in that it is primarily sulphide mineralization located in the Grand Conglomerate unit (Ki1.1) at the base of the Lower Kundelungu Group.

\section{Mineral Resources}

Kamoa-Kakula Mineral Resources (Table I), as defined for the Prefeasibility Study (PFS) and Preliminary Economic Assessment (PEA), are effective 16 May 2017 and are based on drilling up to 5 May 2014 for Kamoa and 18 April 2017 for Kakula.

\section{Recent expansion of Mineral Resource at Kakula (including Kakula West)}

The new estimate boosts the total tonnage of Kakula's Indicated Mineral Resources by 50\%, at a 3\% Cu cut-off, compared with the previous Kakula resource estimate issued in May 2017 that covered a strike length of $7.7 \mathrm{~km}$. The May 2017 resource was used in the 2017 PEA and PFS studies. Kakula's new Indicated Mineral Resources at a 3\% cut-off grade have increased by $58 \mathrm{Mt}$ and currently total $174 \mathrm{Mt}$ at a grade of $5.62 \% \mathrm{Cu}$. This compares with the May 2017 estimate of $116 \mathrm{Mt}$ at $6.09 \% \mathrm{Cu}$, at the same cut-off grade. Estimated Inferred Mineral Resources now total an additional $9 \mathrm{Mt}$ at a grade of $3.66 \% \mathrm{Cu}$, at a 3\% cut-off. At a $1 \% \mathrm{Cu}$ cutoff, Kakula's Indicated Mineral Resources have increased by $58 \%$, now totalling $585 \mathrm{Mt}$ at $2.92 \% \mathrm{Cu}$. 


\section{The giant Kamoa-Kakula project in the Democratic Republic of Congo}

\begin{tabular}{|c|c|c|c|c|c|c|}
\hline \multicolumn{7}{|l|}{ Table I } \\
\hline \multicolumn{7}{|c|}{ Kamoa-Kakula project Mineral Resources (May 2017, 1\% Cu cut-off grade) } \\
\hline \multirow[t]{2}{*}{ Category } & \multirow[t]{2}{*}{ Tonnage (Mt) } & \multirow{2}{*}{ Area $\left(\mathbf{k m}^{2}\right)$} & \multirow{2}{*}{ True thickness (m) } & \multirow{2}{*}{ Copper $(\% \mathrm{Cu})$} & \multicolumn{2}{|c|}{ Contained copper } \\
\hline & & & & & (kt) & (billion lb) \\
\hline $\begin{array}{l}\text { Indicated } \\
\text { Inferred }\end{array}$ & $\begin{array}{c}1101 \\
244\end{array}$ & $\begin{array}{l}60.3 \\
19.8\end{array}$ & $\begin{array}{l}6.3 \\
4.3\end{array}$ & $\begin{array}{l}2.85 \\
2.12\end{array}$ & $\begin{array}{c}31391 \\
5178\end{array}$ & $\begin{array}{l}69.2 \\
11.5\end{array}$ \\
\hline
\end{tabular}

Table II

Kamoa-Kakula Project Mineral Resources (March 2018, 1\% Cu cut-off grade)

\begin{tabular}{|c|c|c|c|c|c|c|}
\hline \multirow[t]{2}{*}{ Category } & \multirow[t]{2}{*}{ Tonnage (Mt) } & \multirow[t]{2}{*}{ Area $\left(\mathrm{km}^{2}\right)$} & \multirow[t]{2}{*}{ True thickness (m) } & \multirow[t]{2}{*}{ Copper $(\% \mathrm{Cu})$} & \multicolumn{2}{|c|}{ Contained copper } \\
\hline & & & & & (kt) & (billion Ib) \\
\hline $\begin{array}{l}\text { Indicated } \\
\text { Inferred }\end{array}$ & $\begin{array}{c}1340 \\
315\end{array}$ & $\begin{array}{l}70.1 \\
24.9\end{array}$ & $\begin{array}{l}6.9 \\
4.6\end{array}$ & $\begin{array}{l}2.72 \\
1.87\end{array}$ & $\begin{array}{c}36600 \\
5890\end{array}$ & $\begin{array}{l}80.7 \\
13.0\end{array}$ \\
\hline
\end{tabular}

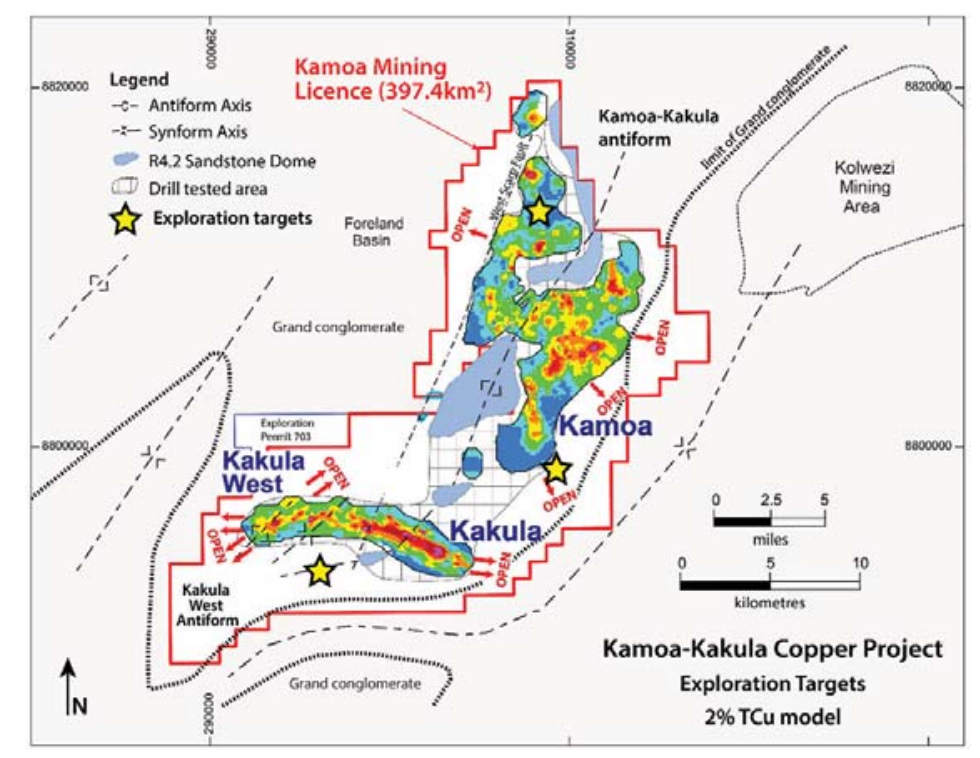

Figure 1-Kamoa-Kakula resource map

The expanded Kamoa-Kakula project Mineral Resources are shown in Table II, and the resource map is shown in Figure 1.

\section{Prefeasibility Study and Preliminary Economic Assessment}

The PFS and PEA were based on the May 2017 Mineral Resource Estimate. The Kakula Mineral Resource has subsequently been significantly expanded and includes the Kakula West extension as summarized above. In November 2017, Ivanhoe issued the results of the Kamoa 2017 PFS and the Kakula 2017 PEA that reflected the updated development scenarios for the Kamoa-Kakula project. The three potential development scenarios examined include:

1. Initial mine development scenario. The Kakula 2017 PEA evaluates the development of a $6 \mathrm{Mt} / \mathrm{a}$ underground mine and surface processing complex at the Kakula deposit (a discovery announced in early 2016) as the project's first phase of development.

2. Expanded two-mine development scenario. The Kakula 2017 PEA also includes an option for an integrated $12 \mathrm{Mt} / \mathrm{a}$ two-stage development, beginning with initial production from the Kakula mine, to be followed by a separate underground mining operation at the nearby Kansoko mine, along with the construction of a smelter.

3. Kamoa 2017 PFS. The Kamoa 2017 PFS evaluates the development of the Kansoko mine as a standalone 6 $\mathrm{Mt} / \mathrm{a}$ underground mine and surface processing complex that would be supplied with ore from the Kansoko Sud and Kansoko Centrale areas of the Kamoa deposit, which were discovered in 2008. The PFS refines the findings of the March 2016 Kamoa PFS, which envisaged a production rate of $3 \mathrm{Mt} / \mathrm{a}$. 


\section{The giant Kamoa-Kakula project in the Democratic Republic of Congo}

\section{Key initial projections from Kakula 2017 PEA}

The study assessed the potential development of the Kakula deposit as a $6 \mathrm{Mt} / \mathrm{a}$ mining and processing complex. The Kakula mill would be constructed in two smaller phases of 3 $\mathrm{Mt} / \mathrm{a}$ each as the mining operations ramped up to full production of $6 \mathrm{Mt} / \mathrm{a}$. The 24 -year life-of-mine production scenario provides for $108.4 \mathrm{Mt}$ to be mined at an average grade of $5.48 \% \mathrm{Cu}$, producing $9.4 \mathrm{Mt}$ of high-grade concentrate, containing approximately 11.4 billion pounds of $\mathrm{Cu}$.

The average annual production rate for the first five years of operation would be $246000 \mathrm{t} \mathrm{Cu}$ at a mine site cash cost of US\$0.45 per pound $\mathrm{Cu}$ and total cash cost of US\$1.08 per pound $\mathrm{Cu}$, with annual production reaching up to $385000 \mathrm{t}$ $\mathrm{Cu}$ by year four.

The estimated initial capital cost, including contingency, is US $\$ 1.2$ billion. The capital expenditure for off-site power, which is included in the initial capital cost, includes a US\$1 million advance payment to the DRC state-owned electricity company, SNEL, to upgrade two hydropower plants (Koni and Mwadingusha) to provide the Kamoa-Kakula project with access to clean electricity for its planned operations. Mwadingusha is being upgraded first. The work is being led by Stucky Ltd., of Switzerland; the advance payment will be recovered through a reduction in the power tariff.

The economic analysis uses a long-term price assumption of US\$3.00 per pound $\mathrm{Cu}$ and returns an after-tax net present value (NPV) at an $8 \%$ discount rate of US\$4.2 billion. It has an after-tax internal rate of return (IRR) of $36.2 \%$ and a payback period of 3.1 years.

The Kakula 2017 PEA envisages a three-year development period, with development of twin underground declines already well underway. The Kakula 2017 PEA's returns for the $6 \mathrm{Mt} / \mathrm{a}$ initial development scenario are set out in Table III for long-term copper prices of $\$ 3.00$ and $\$ 3.50$ per pound. Table IV sets out the mining, processing, production, and operating and capital cost estimates.

\section{Expanded $12 \mathrm{Mt} / \mathrm{a}$ development scenario for Kakula and Kamoa deposits}

The Kakula 2017 PEA also assessed the potential development of the Kakula and Kamoa deposits as an integrated $12 \mathrm{Mt} / \mathrm{a}$ mining and processing complex, built in two stages. This scenario envisages the construction and operation of two separate facilities: an initial mining operation on the Kakula deposit, followed by a, separate mining operation at the Kansoko Sud and Kansoko Centrale areas of the Kamoa deposit.

As this two-stage development scenario was based on delineated resources at the time (announced May 2017), it does not incorporate the mining of any resources that were delineated at the Kakula West discovery and announced in February 2018 or resources that may result from the ongoing drilling of high-priority targets located in the untested parts of the Kamoa-Kakula project area.

Each mining operation is expected to constitute a separate underground mine with a shared processing facility and surface infrastructure. Included in this scenario is the construction of a direct-to-blister flash (DBF) copper smelter with a capacity of $690000 \mathrm{t}$ of copper concentrate per annum. As the resources at the Kakula and Kansoko mines are mined out, production would begin at Kamoa North to maintain a throughput of $12 \mathrm{Mt} / \mathrm{a}$ to the then-existing concentrator and smelter complex.

Table III

Kakula 2017 Preliminary Economic Assessment for long-term copper prices

\begin{tabular}{|l|c|c|}
\hline \multirow{2}{*}{ Parameter } & \multicolumn{2}{|c|}{ Long-term Cu price } \\
\cline { 2 - 3 } & $\mathbf{\$ 3 . 0 0 / \mathbf { l b }}$ & $\mathbf{\$ 3 . 5 0 / \mathbf { l b }}$ \\
\hline Net present value (8\% discount rate, \$ million) & 4243 & 5764 \\
Internal rate of return (\%) & 36.2 & 42.8 \\
Project payback (years) & 3.1 & \\
\hline
\end{tabular}

Table IV

Mining, processing and capital and operating cost estimates for Kakula 2017 PEA

\begin{tabular}{|c|c|c|c|}
\hline Parameter & Total life of mine & & Life-of-mine average \\
\hline $\begin{array}{l}\text { Plant feed milled (kt) } \\
\text { Copper feed grade }(\%) \\
\text { Copper recovery }(\%) \\
\text { Concentrate produced (kt) } \\
\text { Copper concentrate grade }(\%) \\
\text { Contained copper in concentrate (kt) } \\
\text { Contained copper in concentrate (million lb) }\end{array}$ & $\begin{array}{c}108422 \\
9400 \\
5164 \\
11385\end{array}$ & & $\begin{array}{l}4518 \\
5.48 \\
86.9 \\
392 \\
54.9 \\
215 \\
210\end{array}$ \\
\hline & \multicolumn{3}{|c|}{ Payable copper (\$/lb) } \\
\hline $\begin{array}{l}\text { Mine site cash costs } \\
\text { Total cash costs }\end{array}$ & \multicolumn{3}{|c|}{$\begin{array}{l}0.60 \\
1.23\end{array}$} \\
\hline & \multicolumn{3}{|c|}{ Total life of mine } \\
\hline $\begin{array}{l}\text { Peak funding ( } \$ \text { million) } \\
\text { Initial capital cost }(\$ \text { million}) \\
\text { Expansion capital cost }(\$ \text { million) } \\
\text { Sustaining capital cost ( } \$ \text { million) }\end{array}$ & & $\begin{array}{c}1135 \\
1231 \\
318 \\
1443\end{array}$ & \\
\hline
\end{tabular}




\section{The giant Kamoa-Kakula project in the Democratic Republic of Congo}

The 44-year life-of-mine production scenario provides for $444.3 \mathrm{Mt}$ to be mined at an average grade of $3.79 \% \mathrm{Cu}$, producing $34.2 \mathrm{Mt}$ of concentrate, of which $24.5 \mathrm{Mt}$ is smelted internally and 9.7 Mt is sold to external smelters. This produces approximately 30.0 billion pounds of copper cathode and 10.6 billion pounds of copper in concentrate.

The average annual production rate would be $370000 \mathrm{t}$ $\mathrm{Cu}$ at a mine site cash cost of US\$0.63 per pound copper and total cash cost of US\$1.02 per pound, after sulphuric acid credits, for the first ten years of operations, with recovered copper annual production of up to $542000 \mathrm{t}$ by year nine. Given that the first phase is the same as the Kakula $6 \mathrm{Mt} / \mathrm{a}$ initial scenario, estimated initial capital cost, including contingency, is approximately the same, at US $\$ 1.2$ billion. Expansion capital is then funded by using internal cash flows. The economic analysis uses a long-term price assumption of US\$3.00 per pound of copper and returns an after-tax NPV at an 8\% discount rate of US $\$ 7.2$ billion. It has an after-tax IRR of $33.0 \%$ and a payback period of 3.1 years.

The Kakula 2017 PEA's returns, for the expanded 12 Mt/a scenario, are shown in Table V for long-term copper prices of $\$ 3.00$ and $\$ 3.50$ per pound. Table VI sets out the mining, processing, production, and operating and capital cost estimates.

\section{Summary of key results for the Kamoa 2017 Prefeasibility Study}

In addition to the PEA, a PFS was completed for the development of a $6 \mathrm{Mt} / \mathrm{a}$ Kansoko mine at the Kamoa deposit. This refined the findings of the Kamoa March 2016 PFS, which envisaged a production rate of $3 \mathrm{Mt} / \mathrm{a}$.

The PFS is based entirely on the Kamoa 2017 PFS Mineral Reserve, details of which are shown in a section below. The PFS re-assessed the development of the Kamoa deposit as a standalone $6 \mathrm{Mt} / \mathrm{a}$ mining and processing complex. The 26-year life-of-mine production scenario schedules $125.2 \mathrm{Mt}$ to be mined at an average grade of $3.81 \% \mathrm{Cu}$, producing $11.4 \mathrm{Mt}$ of high-grade copper concentrate containing approximately 9.2 billion pounds $\mathrm{Cu}$.

The average annual production rate would be $178000 \mathrm{t}$ $\mathrm{Cu}$ at a mine site cash cost of US\$0.57 per pound $\mathrm{Cu}$ and total cash cost of US\$ 1.44 per pound $\mathrm{Cu}$ for the first ten years of operation, with an annual production of up to 245 $000 \mathrm{t} \mathrm{Cu}$ by year seven. The estimated initial capital cost, including contingency, is US\$1.0 billion.

The economic analysis used a long-term price assumption of US\$3.00 per pound $\mathrm{Cu}$ and returns an after-tax NPV at an $8 \%$ discount rate of US\$2.1 billion, which is an increase of $110 \%$ compared with the after-tax NPV8\% of US $\$ 986$ million that was projected in the Kamoa 2016 PFS. It has an aftertax IRR of $24.2 \%$ and a payback period of 5.0 years. The estimated initial capital cost, including contingency, is US\$1.0 billion.

The Kamoa 2017 PFS returns, at a production rate of 6 $\mathrm{Mt} / \mathrm{a}$, are shown in Table VII for long-term copper prices of $\$ 3.00$ and $\$ 3.50$ per pound. Table VIII summarizes the mining, processing, production, and operating and capital cost estimates.

Table $\mathrm{V}$

Kakula 2017 expanded scenario Preliminary Economic Assessment for long-term copper prices

\begin{tabular}{|l|c|c|}
\hline \multirow{2}{*}{ Parameter } & \multicolumn{2}{|c|}{ Long-term Cu price } \\
\cline { 2 - 3 } & $\mathbf{\$ 3 . 0 0 / \mathbf { l b }}$ & $\mathbf{\$ 3 . 5 0 / \mathbf { l b }}$ \\
\hline Net present value (8\% discount rate, \$ million) & 7179 & 9808 \\
Internal rate of return (\%) & 33.0 & 39.6 \\
Project payback (years) & 4.7 & \\
\hline
\end{tabular}

Table VI

Mining, processing, and capital and operating cost estimates for Kakula 2017 expanded scenario

\begin{tabular}{|c|c|c|}
\hline Parameter & Total life of mine & Life-of-mine average \\
\hline $\begin{array}{l}\text { Plant feed milled (kt) } \\
\text { Copper feed grade }(\%) \\
\text { Copper recovery }(\%) \\
\text { Concentrate produced }(\mathrm{kt}) \\
\text { Concentrate smelted (kt) } \\
\text { Concentrate sold }(\mathrm{kt}) \\
\text { Copper concentrate grade }(\%) \\
\text { Contained copper in blister (kt) } \\
\text { Contained copper in blister (million lb) } \\
\text { Contained copper in concentrate (kt) } \\
\text { Contained copper in concentrate (million lb) }\end{array}$ & $\begin{array}{c}444276 \\
\\
34206 \\
24461 \\
9744 \\
\\
9505 \\
20955 \\
4820 \\
10627\end{array}$ & $\begin{array}{l}10079 \\
3.79 \\
86.0 \\
777 \\
556 \\
221 \\
42.3 \\
216 \\
476 \\
110 \\
242\end{array}$ \\
\hline & \multicolumn{2}{|c|}{ Payable copper (\$/lb) } \\
\hline $\begin{array}{l}\text { Mine site cash costs } \\
\text { Total cash costs (after credits) }\end{array}$ & \multicolumn{2}{|c|}{$\begin{array}{l}0.78 \\
1.20\end{array}$} \\
\hline & \multicolumn{2}{|c|}{ Total life of mine } \\
\hline $\begin{array}{l}\text { Peak funding ( } \$ \text { million) } \\
\text { Initial capital cost }(\$ \text { million) } \\
\text { Expansion capital cost }(\$ \text { million }) \\
\text { Sustaining capital cost }(\$ \text { million) }\end{array}$ & & \\
\hline
\end{tabular}




\section{The giant Kamoa-Kakula project in the Democratic Republic of Congo}

Table VII

Kakula 2017 Prefeasibility Study returns for long-term copper prices

\begin{tabular}{|l|c|c|}
\hline \multirow{2}{*}{ Parameter } & \multicolumn{2}{|c|}{ Long-term Cu price } \\
\cline { 2 - 3 } & $\$ 3.00 / \mathbf{l b}$ & $\$ 3.50 / \mathrm{lb}$ \\
\hline Net present value (8\% discount rate, \$ million) & 2063 & 3126 \\
Internal rate of return (\%) & 24.2 & 30.5 \\
Project payback (years) & 5.0 & \\
\hline
\end{tabular}

Table VIII

Mining, processing, and capital and operating cost estimates for the Kamoa 2017 PFS

\begin{tabular}{|c|c|c|}
\hline Parameter & Total life of mine & Life-of-mine average \\
\hline $\begin{array}{l}\text { Plant feed milled (kt) } \\
\text { Copper feed grade }(\%) \\
\text { Copper recovery }(\%) \\
\text { Concentrate produced (kt) } \\
\text { Copper concentrate grade }(\%) \\
\text { Contained copper in concentrate (kt) } \\
\text { Contained copper in concentrate (million lb) }\end{array}$ & $\begin{array}{l}125182 \\
11405 \\
9211 \\
4178\end{array}$ & $\begin{array}{l}4815 \\
3.81 \\
87.5 \\
439 \\
36.6 \\
354 \\
161\end{array}$ \\
\hline & \multicolumn{2}{|c|}{ Payable copper (\$/lb) } \\
\hline $\begin{array}{l}\text { Mine site cash costs } \\
\text { Total cash costs }\end{array}$ & \multicolumn{2}{|c|}{0.64} \\
\hline & \multicolumn{2}{|c|}{ Total life of mine } \\
\hline Peak funding (\$ million) & \multicolumn{2}{|c|}{1070} \\
\hline Initial capital costs ( $\$$ million) & \multicolumn{2}{|c|}{1004} \\
\hline Expansion capital costs (\$ million) & \multicolumn{2}{|c|}{348} \\
\hline Sustaining capital costs ( $\$$ million) & \multicolumn{2}{|c|}{1334} \\
\hline
\end{tabular}

\section{Mining at Kamoa}

The Kamoa 2017 PFS includes a Probable Mineral Reserve of approximately $125.2 \mathrm{Mt}$ grading at $3.81 \% \mathrm{Cu}$, which has been defined in multiple mining zones to support a $6 \mathrm{Mt} / \mathrm{a}$ production rate over a 26-year mine life. The PFS targets the Kansoko Sud and Kamoa Centrale areas of the Kamoa resource. These ore zones occur at depths ranging from approximately $60 \mathrm{~m}$ to $1235 \mathrm{~m}$. Access to the mine will be via twin declines. Mining will be by the room and pillar $(R \& P)$ method for areas between $60 \mathrm{~m}$ and $150 \mathrm{~m}$ and controlled convergence $R \& P(C C R \& P)$ for mineralized zones below $150 \mathrm{~m}$. The methods were modified from previous studies.

Based on the positive results of the CCR\&P validation study completed in 2016 by KGHM Cuprum Ltd., Kamoa Copper engaged KGHM Cuprum to provide CCR\&P design criteria, schedule inputs, panel sequencing, and technical contributors for the PFS.

The production development of the R\&P method will be in a grid-like fashion, using $7.0 \mathrm{~m}$ wide drifts. The room development will run parallel to the strike of the panel for dips less than $20^{\circ}$, with belt drives running at an acute angle to the room drifts. Where the dip is greater than $20^{\circ}$, the rooms will be developed slightly off strike to accommodate the acute angle between the room development and the belt drives. The R\&P areas, designed to prevent subsidence, will be accessible if maintained and ventilated.

CCR\&P mining will be used in the mineralization zones below $150 \mathrm{~m}$. An initial panel will be taken as a trial to further define the design criteria, operational procedures, and geotechnical monitoring programmes. The production schedule is based on mining $70 \%$ of the trial panel prior to commencing additional CCR\&P panels.

$C C R \& P$ mining is based on the strength and strain parameters of the rock that makes up the mining panel supporting pillar or technological pillars, and includes the following parameters:

$>$ Ore zone below $150 \mathrm{~m}$

> Strength of the immediate roof (i.e., roofbolting and handling of the rockburst threat)

$>$ Strength and strain parameters of the rocks within the roof of the extraction panel (i.e., the slow bending above the extraction space and in the workings)

> Technological pillars (pillars between rooms) designed to work in post-destruction strength state to maximize ore extraction.

The development schedule focuses on the establishment of necessary mine services and support infrastructure to set 


\section{The giant Kamoa-Kakula project in the Democratic Republic of Congo}

up the initial production mining areas and ramp up to $6 \mathrm{Mt} / \mathrm{a}$ ore production and associated development waste. The development schedule is broken down into the following three main phases:

> Phase 1: development of the declines to the main ore bins

> Phase 2: R\&P mining and CCR\&P pillar trial panel

> Phase 3: development of Centrale and Sud mining areas. criteria:

The production schedule is based on the following

> Proximity to the main access and early development

- High grade and thickness

> Mining direction

> Panel sequencing follows a declining copper grade profile.

The production will ramp up over a five-year period, achieving full production by year six. The schedule maintains full production for 17 years with an overall mine life of 26 years. The schedule is developed to mine a portion of the ore tonnage from Kansoko Sud while the majority of the ore production is from Centrale mining area.

\section{Mining at Kakula}

Kamoa Copper prepared a mining method selection study for the thicker portions of the Kakula deposit that analysed the resource geometry, grade distribution, ore thickness, and preliminary geotechnical information to determine the most appropriate mining methods. The study also included key criteria such as extraction percentage, design flexibility, productivities, and safety in the evaluation to ensure the selection process was all-encompassing. The results of the study indicate that drift-and-fill with paste fill $(D \& F)$ is the preferable method for the high-grade portion of the Kakula resource greater than $6 \mathrm{~m}$ thick. This method meets all evaluation objectives. The D\&F method has a greater amount of flexibility related to challenges that will be encountered, such as steeply dipping portions of the deposit and groundwater.
In parallel with the mining method selection study for the thicker area, Kamoa engaged KGHM Cuprum to investigate the areas of the resource ranging between $3 \mathrm{~m}$ and $6 \mathrm{~m}$ in thickness and with dips from $12^{\circ}$ to $25^{\circ}$ for possible application of CCR\&P mining methods. The CCR\&P validation study included geotechnical drilling and test work that compared the rock properties and geotechnical parameters between Kakula and the KGHM orebody in Poland. The results of the study were positive, indicating that the method can be applied to Kakula.

The two mining methods selected for the 2017 Kakula $P E A$ were $D \& F$ and $C C R \& P$. There is further work required during the ongoing 2018 PFS to further refine the mining method design criteria and associated inputs to confirm the assumptions used in the PEA. The mine layout is shown in Figure 2.

\section{Metallurgical test work and concentrator design}

Between 2010 and 2015, a series of metallurgical test work programmes was completed on drill-core samples of Kamoa mineralization. These investigations focused on metallurgical characterization and flow sheet development for the processing of hypogene and supergene copper mineralization.

In 2016, further bench-scale metallurgical flotation test work was carried out at XPS Consulting and Testwork Services laboratories in Falconbridge, Ontario, Canada. This work was conducted on composite samples of drill core from the Kansoko Sud and Kansoko Centrale areas in the southern part of the Kamoa Mineral Resource area. The flow sheet developed was suited for the fine-grained nature of the material and yielded positive results. Test work on a composite grading $3.61 \% \mathrm{Cu}$ produced a copper recovery of $85.4 \%$ at a concentrate grade of $37.0 \% \mathrm{Cu}$. The second composite, grading $3.20 \% \mathrm{Cu}$, produced a copper recovery of $89.2 \%$ at a concentrate grade of $35.0 \% \mathrm{Cu}$ using the same flow sheet.

Additional bench-scale metallurgical flotation test work was carried out in 2016 on two chalcocite-rich composites from the Kakula deposit at a Zijin Mining laboratory in Xiamen, China and by XPS Consulting and Testwork

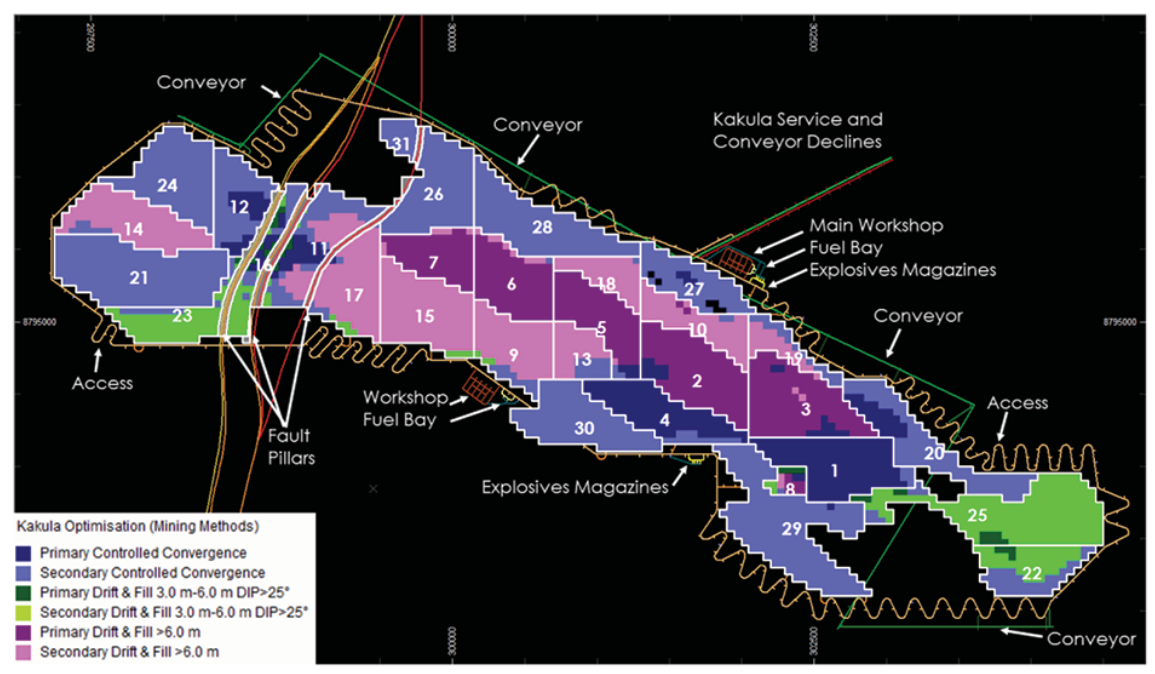

Figure 2-Kakula mine layout 


\section{The giant Kamoa-Kakula project in the Democratic Republic of Congo}

Services. The initial composite, grading $4.1 \% \mathrm{Cu}$, produced a copper recovery of $86 \%$ at a concentrate grade of $53 \% \mathrm{Cu}$ at the Zijin Mining laboratory in July 2016. The second composite, grading $8.1 \% \mathrm{Cu}$, produced a recovery of $87 \%$ at an extremely high concentrate grade of $56 \% \mathrm{Cu}$. The flotation tests were conducted using the circuit developed during the 2016 Kamoa PFS.

Average arsenic levels in the concentrate were measured as approximately $0.02 \%$, which is significantly lower than the limit of $0.5 \%$ imposed by Chinese smelters. Extremely low arsenic levels in concentrate are expected to attract a premium from copper concentrate traders.

The concentrator design (Figure 3) incorporates a run-ofmine stockpile followed by primary and secondary crushing on surface. The crushed material, with a design size distribution of $80 \%$ passing (or $\left.P_{80}\right) 9 \mathrm{~mm}$, is fed into a twostage ball-milling circuit for further size reduction to a target grind size $P_{80}$ of $53 \mu \mathrm{m}$. The milled slurry will be passed through a rougher and scavenger flotation circuit. The highgrade, or fast-floating, rougher concentrate and mediumgrade, or slow-floating, scavenger concentrate will be collected separately. The rougher concentrate is upgraded in two stages to produce a high-grade concentrate. The medium-grade scavenger concentrate and tailings from the two rougher cleaning stages, representing approximately $25 \%$ of the feed mass, will be combined and re-ground to a $P_{80}$ of $10 \mu \mathrm{m}$ before being cleaned in two stages. The cleaned scavenger concentrate will then be combined with the cleaned rougher concentrate to form the final concentrate. The final concentrate will be thickened before being pumped to the concentrate filter where the filter cake will be bagged for shipment to market.

\section{Direct-to-blister smelting}

Under the $12 \mathrm{Mt} / \mathrm{a}$ scenario examined in the Kakula 2017 PEA, the construction of a DBF smelter is envisaged, subject to further studies on feasibility, scale, and timing. Flash smelting is typically advantageous compared with other technologies because the energy costs are relatively low.

The smelter is designed with a capacity of $690000 \mathrm{t}$ of concentrate, and would operate at full capacity fed by KamoaKakula copper concentrates until the end of the mine life. Concentrate would be first dried and sent to the DBF, where it is smelted in the reaction shaft with oxygen-enriched air to produce blister copper, molten slag containing oxide minerals, and $\mathrm{SO}_{2}$-rich off-gas. The oxidation reactions provide sufficient heat required to melt the charge, although a small amount of external fuel is used for process control purposes. Molten slag and blister copper collect in the DBF furnace settler and are intermittently tapped via dedicated tap-holes. The slag is reduced in two electric slag-cleaning furnaces operating in series to recover copper in the form of blister and alloy, respectively. The $\mathrm{SO}_{2}$-rich off-gas is de-dusted, dried, and sent to a double-contact double-adsorption acid plant for production of high-strength sulphuric acid that is sold to the local market.

An on-site smelter offers numerous cost savings, including on treatment charges, certain royalties, and transportation costs, particularly for the lower-grade copper concentrates from the Kansoko and Kamoa North mines. The sale of the sulphuric acid by-product would generate additional revenue. Sulphuric acid is in short supply in the $\mathrm{DRC}$ and is imported for use in processing ore from oxide copper deposits.

\section{Infrastructure}

Because the Kamoa-Kakula project is a greenfield project, it will require the development of new infrastructure to conduct mining and processing operations. In addition to mine development and processing infrastructure, Kamoa Copper contemplates developing power, transportation, water, housing, and other ancillary infrastructure.

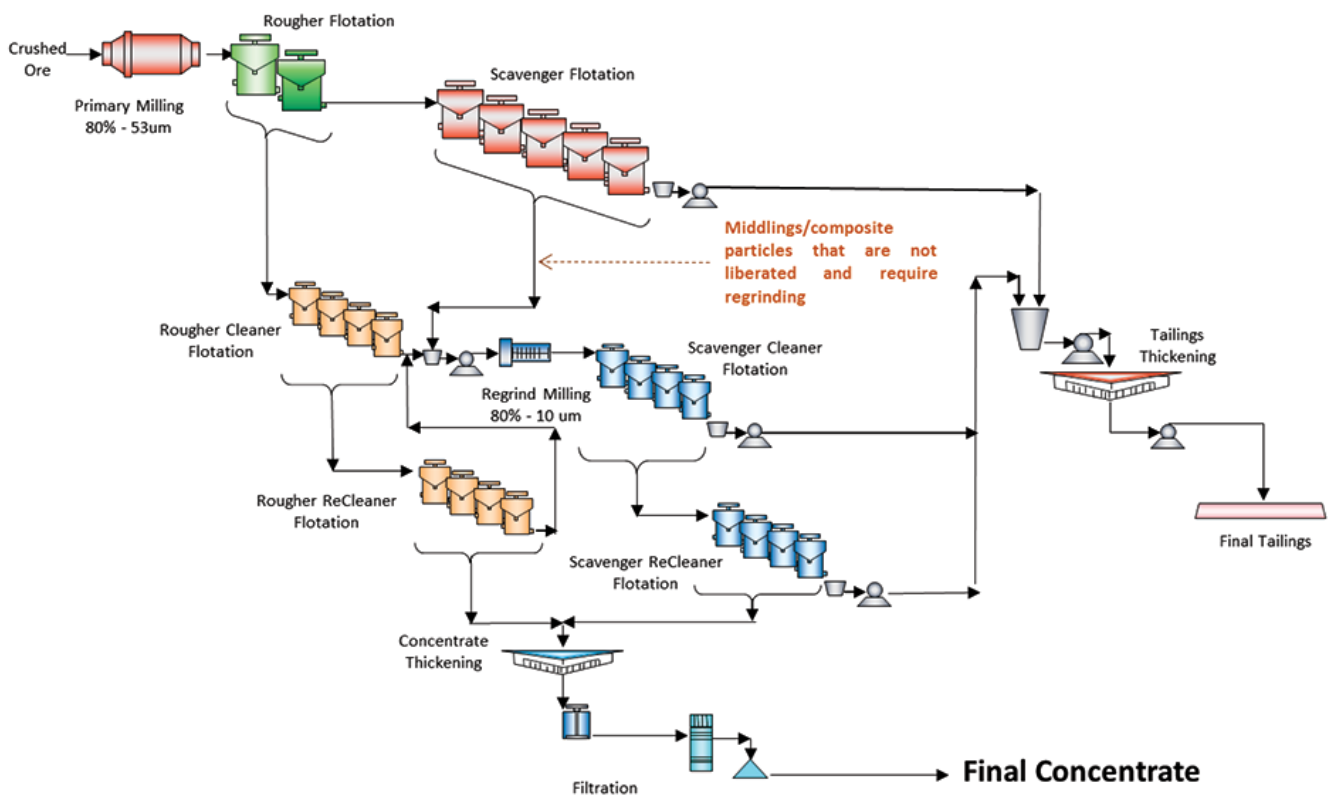

Figure 3-Concentrator flow sheet 


\section{The giant Kamoa-Kakula project in the Democratic Republic of Congo}

Kamoa Holding is in the process of securing sources of power through a joint development with SNEL. In June 2011, a Memorandum of Understanding (MOU) with SNEL was executed, by which the parties agreed to rehabilitate two existing hydroelectric plants, Mwadingusha and Koni, that have an aggregate generation capacity of $113 \mathrm{MW}$. The cost of the rehabilitation will be financed by Kamoa Holding through a loan to SNEL, although the projects will be jointly developed. The loan will be repaid by SNEL through a deduction from the monthly power bills incurred over the life of the loan. The MOU contemplates that, following such an upgrade, Kamoa Holding would have an entitlement of up to $100 \mathrm{MW}$ from these facilities, which the company believes to be sufficient for the infrastructure contemplated in the mine plan for the initial concentrate phase. The MOU led to the signing of a pre-financing agreement with SNEL in June 2012 for rehabilitation works on the Mwadingusha power plant. This pre-financing agreement stipulates the exclusive right to conduct full rehabilitation on both the Mwadingusha and Koni plants.

In April 2013, a further MOU with SNEL was signed to upgrade a third hydroelectric power plant, Nzilo 1, to its design capacity of 111 MW. Similar to the June 2011 MOU, Kamoa Holding would finance the refurbishment of Nzilo 1 through a repayable loan to SNEL and SNEL would grant Kamoa Holding a priority entitlement to power from the power grid. Nzilo 1, Mwadingusha, and Koni could produce a combined total of up to $200 \mathrm{MW}$, which is believed to be sufficient for the infrastructure contemplated in the subsequent, expansion phase.

In March 2014, the company signed a financing agreement with SNEL governing the terms of the rehabilitation of three power plants and associated nearby transmission lines and substations. Transmission lines that run within $10 \mathrm{~km}$ of the Kamoa-Kakula Project have now been extended to the project.

In January 2018, the company announced that the completion of rehabilitation of three of the six generators at Mwadingusha had increased interim power output to $32 \mathrm{MW}$ ( $45 \%$ of the plant's designed capacity of $71 \mathrm{MW}$ ), with the remaining three generators due to be upgraded and fully operational by the end of 2019 .

A phased logistics solution is proposed in the Kakula 2017 PEA. Initially, the corridor between southern DRC and Durban in South Africa is viewed as the most attractive and reliable export route. As soon as the railway between Kolwezi and Dilolo, a town near the DRC-Angola border, is upgraded, the Kamoa-Kakula project's production is expected to be transported by rail to the Atlantic port of Lobito in Angola. In addition, there is the potential to negotiate offtake arrangements with smelters in Zambia.

Water is abundant in the area and Kamoa Copper anticipates that it will be able to secure a nearby water source for its operations as part of further mine development planning. Preliminary water studies have identified both underground and surface water sources, specifically the aquifer developed within the sandstone forming the Kamoa and Makalu domes and the footwall to the mining operations, and the Mutaka Dam, approximately $13 \mathrm{~km}$ to the east of the proposed plant site.
Kamoa Holding contemplates constructing office and administrative facilities, an employee village with housing, recreation, and other amenities, including a medical facility and other associated infrastructure.

\section{Markets and contracts}

To date, Kamoa Copper has not advanced contract and market studies, apart from an initial analysis of potential sale of concentrate to Zambian and international smelters. Kamoa Copper continues to maintain a dialogue with numerous smelters in the region.

\section{Environmental, social, and community}

The company conducted an environmental baseline study that analysed environmental, biological, social, and cultural heritage issues. As the Kamoa-Kakula project is in a sparsely inhabited area, to date no significant environmental, social, or community risks have been identified.

Numerous community projects have been completed to date, including:

> The construction of three schools, including equipping

- A community water project

- Farming and agricultural projects

> The construction of a community centre

- Construction of two poultry projects

$>$ Training and job creation.

\section{Project development}

Following the publication of the Kakula 2017 PEA, a PFS for a $6 \mathrm{Mt} / \mathrm{a}$ operation is underway, with completion targeted for the second half of 2018. In addition, following the publication of an expanded Mineral Resource for Kakula, including Kakula West, on 26 February 2018, work is underway to update the Kamoa-Kakula development plan to include these new resources in the mine plan.

Underground development work on the twin declines at Kakula is progressing according to plan. Each decline has been advanced more than $250 \mathrm{~m}$, approximately $15 \%$ of the projected total distance. The Kakula boxcut was successfully completed on 26 October 2017 and the first blast for the twin declines took place on 16 November 2017. The Kakula decline development work is being undertaken by JMMC, a DRC subsidiary of JCHX Mining Management of Beijing, China. Depending on ground conditions, the $3600 \mathrm{~m}$ decline development contract is scheduled for completion around the end of 2018. In addition to the declines, other project development works planned for 2018 include terracing, the construction of a mine access road from Kolwezi airport, and other surface infrastructure at the Kakula camp.

\section{Bibliography}

NI 43-101 Technical Report, Kamoa-Kakula 2017 Development Plan, January 2018. https://www.ivanhoemines.com/site/assets/files/3634/kamoakakula_2017_development_plan_-_january_2018.pdf

NI 43-101 Technical Report, Kamoa-Kakula 2018 Resource Update, March 2018. https://www.ivanhoemines.com/site/assets/files/3736/kamoakakula-2018-resource-update-march-2018.pdf 